\title{
STATUS GIZI BERPENGARUH TERHADAP PERKEMBANGAN ANAK USIA 1-2 TAHUN
}

\author{
Nurul Misbah*, Ahmad*, Darti Rumiatun*.
}

\begin{abstract}
Abstrak
Prevalensi anak usia 1-2 tahun gizi kurang atau anak usia 1-2 tahun kurus masih tinggi. Keadaan gizi kurang dapat menyebabkan gangguan pertumbuhan dan perkembangan, khusus pada perkembangan dapat mengakibatkan perubahan struktur dan fungsi otak. Di Indonesia diperkirakan sekitar 30,8 \% anak berumur 0-13 tahun mengalami keterlambatan perkembangan motorik kasarnya.

Tujuan penelitian ini adalah untuk memahami fenomena antara status gizi, jenis kelamin, pendidikan, pekerjaan, ekonomi dan pola asuh dengan Perkembangan Anak usia 1-2 tahun di Puskesmas kecamatan Warungunung Kabupaten Lebak tahun 2013. Jenis penelitian ini adalah deskriptif analitik dengan pendekatan cross sectional. Jumlah sampel 100 responden dan cara pengambilan sampel dengan accidental sampling. Analisis data dengan univariat, bivariat dan multivariat.

Hasil penelitian menunjukkan bahwa status gizi mempunyai hubungan yang bermakna dengan perkembangan anak usia 1-2 tahun, sementara variabel jenis kelamin anak, pendidikan ibu, pekerjaan ibu, status sosial ekonomi dan pola asuh tidak berhubungan. Hasil analisis multivariat menunjukkan bahwa yang diduga berhubungan dengan perkembangan anak usia 1-2 tahun, ternyata hanya variabel status gizi yang secara signifikan berhubungan dengan perkembangan anak usia 1-2 tahun.

Saran bagi Petugas kesehatan hendaknya melakukan pemantauan perkembangan anak sesuai dengan program Puskesmas secara rutin khususnya pada anak usia keemasan (golden age). Sekaligus memberikan penjelasan pada ibu yang memiliki anak usia keemasan tersebut tentang manfaat dan pentingnya gizi bagi pertumbuhan dan perkembangan anak.
\end{abstract}

\section{Kata Kunci : Status Gizi, Perkembangan anak usia 1-2 tahun, Puskesmas Warungunung}

* Poltekkes Kemenkes Banten

\section{Pendahuluan}

Kekurangan gizi khususnya kekurangan energi protein (KEP) masih merupakan masalah kesehatan masyarakat di Indonesia. Prevalensi anak usia 1-2 tahun gizi kurang atau anak usia 12 tahun kurus masih tinggi. Berdasarkan Riset Kesehatan Dasar (RISKESDAS) 2007 prevalensi gizi kurang (BB/U <-2SD WHO 2006 ) 18,4\% dan anak usia 1-2 tahun kurus $(\mathrm{BB} / \mathrm{TB}<-2 \mathrm{SD})$ 13,6\%. Hal tersebut menunjukkan meskipun prevalensi gizi kurang sudah menurun lebih rendah dari target pembangunan kesehatan Indonesia 2009 yaitu 20\% dan pencapaian Millenium Development Goals (MDGs) 2015, $18,5 \%$ namun prevalensi anak usia 1-2 tahun kurus masih tinggi. 
Makanan yang kurang baik secara kualitas maupun kuantitas akan menyebabkan gizi kurang. Keadaan gizi kurang dapat menyebabkan gangguan pertumbuhan dan perkembangan, khusus pada perkembangan dapat mengakibatkan perubahan struktur dan fungsi otak.

Data yang diperoleh dari Puskesmas kecamatan Warunggunung pada bulan Januari 2013, berdasarkan hasil penimbangan dari 2112 anak usia 0-59 bulan terdapat 28 orang berada dibawah garis bawah merah (BGM) pada KMS dimana termasuk katagori gizi kurang. Sedangkan pemeriksaan pertumbuhan dan perkembangan anak di Puskesmas menurut pengakuan bidan di Puskesmas kecamatan Warunggunung, belum pernah dilakukan. Oleh karena itu penulis ingin mencoba melakukan penelitian, apakah ada hubungan antara status gizi dengan perkembangan anak khususnya pada tahun pertama kehidupannya (1-2 tahun).

\section{Metode Penelitian}

Desain penelitian yang digunakan dalam penelitian ini adalah Cross Sectional. Desain study Cross Sectional. Populasi adalah semua ibu yang memiliki anak berusia 1-2 tahun di wilayah Kerja Puskesmas Warunggunung, sampel sebanyak 100 ibu yang memiliki anak usia 1-2 tahun. Pengumpulan data dilakukan melalui kuesioner.

Data yang terkumpul selanjutnya diolah dan dianalisis secara univariat, bivariat dan multivariat.

\section{Hasil Penelitian}

Tabel 1. Distribusi freuensi Responden berdasarkan Perkembangan anak usia 1-2 tahun, status gizi anak, jenis kelamin anak, pendidikan ibu, pekerjaan ibu, status sosial ekomoni dan pola asuh.

\begin{tabular}{lcc}
\hline Variabel & Frekuensi & Persen \\
\hline Perkembangan anak usia & & \\
1-2 tahun & & \\
$\quad$ Ada Penyimpangan & 23 & 23,0 \\
$\quad$ Normal & 77 & 77,0 \\
\hline Status Gizi & & \\
$\quad$ Kurang & 29 & 29,0 \\
$\quad$ Normal & 71 & 71,0 \\
\hline Jenis kelamin & & \\
$\quad$ Perempuan & 70 & 70,0 \\
Laki-laki & 30 & 30,0 \\
\hline Pendidikan Ibu & & \\
$\quad$ Rendah & 79 & 79,0 \\
$\quad$ Tinggi & 21 & 21,0 \\
\hline Pekerjaan ibu & & \\
$\quad$ Bekerja & 4 & 4,0 \\
$\quad$ Tidak bekerja & 96 & 96,0 \\
\hline Penghasilan Keluarga & & \\
$\quad$ Rendah & 84 & 84,0 \\
Tinggi & 16 & 16,0 \\
\hline Pola Asuh/Latihan & & \\
Kurang & 12 & 12,0 \\
Baik & 88 & 88,0 \\
\hline Jumlah & 100 & 100,0 \\
\hline
\end{tabular}

Dari Tabel 1 dapat digambarkan bahwa masih terdapat penyimpangan perkembangan pada anak usia 1-2 tahun (23\%), jenis kelamin anak lebih banyak perempuan $(70 \%)$, pendidikan ibu masih banyak yang rendah (79\%), ibu lebih banyak yang tidak bekerja (96\%) penghasilan keluarga masih banyak yang rendah (84\%) pola asuh/latihan dilakukan keluarga lebih banyak yang baik $(88 \%)$. 
Tabel 2. Hubungan Status Gizi dengan Perkembangan Anak Usia 1-2 tahun

\begin{tabular}{|c|c|c|c|c|c|c|c|c|}
\hline \multirow{3}{*}{ Variabel } & \multicolumn{4}{|c|}{ Perkembangan anak usia 1-2 tahun } & \multirow{2}{*}{\multicolumn{2}{|c|}{ Jumlah }} & \multirow{3}{*}{$\begin{array}{c}\text { P- } \\
\text { value }\end{array}$} & \multirow{3}{*}{ OR } \\
\hline & \multicolumn{2}{|c|}{ Ada penyimpangan } & \multicolumn{2}{|c|}{ Normal } & & & & \\
\hline & $\mathrm{F}$ & $\%$ & $\mathrm{~F}$ & $\%$ & $\mathrm{~F}$ & $\%$ & & \\
\hline \multicolumn{9}{|l|}{ Status Gizi } \\
\hline Kurang & 19 & 65,5 & 10 & 34,5 & 29 & 100 & \multirow{2}{*}{0,00} & 31,825 \\
\hline Baik & 4 & 5,6 & 67 & 94,4 & 71 & 100 & & $(8,969-112,928)$ \\
\hline \multicolumn{9}{|l|}{ Jenis Kelamin } \\
\hline Perempuan & 16 & 22,9 & 54 & 77,1 & 70 & 100 & \multirow{2}{*}{1,00} & - \\
\hline Laki-laki & 7 & 22,3 & 23 & 76,7 & 30 & 100 & & \\
\hline \multicolumn{9}{|l|}{ Pendidikan Ibu } \\
\hline Rendah & 19 & 24,1 & 60 & 75,9 & 70 & 100 & \multirow{2}{*}{0,77} & \multirow[t]{2}{*}{-} \\
\hline Tinggi & 4 & 19,0 & 17 & 81,0 & 30 & 100 & & \\
\hline \multicolumn{9}{|l|}{ Pekerjaan } \\
\hline Bekerja & 1 & 25,0 & 3 & 75,0 & 4 & 100 & \multirow{2}{*}{1,00} & \multirow[t]{2}{*}{-} \\
\hline Tidak Bekerja & 22 & 22,9 & 74 & 77,1 & 96 & 100 & & \\
\hline \multicolumn{9}{|c|}{ Ekonomi keluarga } \\
\hline Rendah & 21 & 25,0 & 63 & 75,0 & 64 & 100 & \multirow{2}{*}{1,00} & \multirow[t]{2}{*}{-} \\
\hline Tinggi & 2 & 12,5 & 14 & 87,5 & 16 & 100 & & \\
\hline
\end{tabular}

Dari Tabel 2. diatas menunjukkan bahwa penyimpangan perkembangan anak usia 1-2 tahun proporsinya lebih banyak pada anak dengan status gizi kurang $(65,5 \%)$ dibandingkan pada anak dengan status gizi baik $(5,6 \%)$. Hasil uji ststistik chi square pada alpha 0,05 diperoleh nilai 0,000 $(\mathrm{p}<0,05)$, yang berarti bahwa secara ststistik ada hubungan antara Perkembangan anak usia 1-2 tahun dengan ststus gizi. Hasil analisis lebih lanjut diperoleh nilai $\mathrm{OR}=31,825$ yang berarti bahwa anak dengan status gizi kurang beresiko mengalami penyimpangan perkembangan 32 kali dibandingkan anak dengan gizi baik.

Hubungan perkembangan anak usia 1-2 tahun dengan jenis kelamin menunjukkan bahwa penyimpangan perkembangan anak usia 1-2 tahun proporsinya hampir sama antara anak dengan jenis kelamin Perempuan $(22,9 \%)$ dengan anak berjenis 
kelamin laki-laki (22,3\%). Hasil uji ststistik chi square pada alpha 0,05 diperoleh nilai 1,000 ( $>0,05)$, yang berarti bahwa secara ststistik tidak ada hubungan antara Perkembangan anak usia 1-2 tahun dengan jenis kelamin.

Hubungan Pendidikan ibu dengan Perkembangan anak usia 1-2 tahun. menunjukkan bahwa penyimpangan perkembangan anak usia 1-2 tahun proporsinya hampir sama antara anak dengan jenis kelamin Perempuan (22,9\%) dengan anak berjenis kelamin laki-laki (22,3\%). Hasil uji ststistik chi square pada alpha 0,05 diperoleh nilai 1,000 ( $>>0,05)$, yang berarti bahwa secara ststistik tidak ada hubungan antara Perkembangan anak usia 1-2 tahun dengan jenis kelamin. Hubungan Pendidikan ibu dengan Perkembangan anak usia 12 tahun.

Hubungan Pekerjaan ibu dengan Perkembangan anak usia 1-2 tahun menunjukkan bahwa penyimpangan perkembangan anak usia 1-2 tahun proporsinya lebih banyak pada ibu yang bekerja (25\%) dibandingkan ibu yang tidak bekerja $(22,9 \%)$.

Hasil uji ststistik chi square pada alpha 0,05 diperoleh nilai $1,000(p>0,05)$, yang berarti bahwa secara ststistik tidak ada hubungan antara Perkembangan anak usia 1-2 tahun pendidikan ibu.

Hubungan Ekonomi Keluarga dengan Perkembangan anak usia 1-2 tahun menunjukkan bahwa penyimpangan perkembangan anak usia 1-2 tahun proporsinya lebih banyak pada keluarga dengan ekonomi rendah (25,0\%) dibandingkan pada keluarga dengan ekonomi tinggi (12,5\%). Hasil uji ststistik chi square pada alpha 0,05 diperoleh nilai $0,349(p>0,05)$, yang berarti bahwa secara ststistik tidak ada hubungan antara Perkembangan anak usia 1-2 tahun dengan tingkat ekonomi kelarga.

Hubungan Pola asuh/Latihan dengan Perkembangan anak usia 1-2 tahun menunjukkan bahwa penyimpangan perkembangan anak usia 1-2 tahun proporsinya lebih banyak pada pola asuh keluarga kurang $(25,0 \%)$ dibandingkan dengan pola asuh keluarga baik $(22,7 \%)$. Hasil uji ststistik chi square pada alpha 0,05 diperoleh nilai 1,000 ( $>>0,05)$, yang berarti bahwa secara ststistik tidak ada hubungan antara Perkembangan anak usia 1-2 tahun dengan pola asuh/latihan yang dilakukan keluarga

Tabel 3. Variabel yang masuk dalam model awal multivariat. Hubungan Status Gizi dengan Perkembangan anak usia 1-2 tahun.

\begin{tabular}{rrrc}
\hline Variabel & \multicolumn{1}{c}{$\mathrm{Pv}$} & \multicolumn{1}{c}{ OR } & \multicolumn{1}{c}{$95 \%$ CI } \\
\hline Status Gizi & 0.000 & 31,825 & $8,969-112,928$ \\
$\begin{array}{l}\text { Pola asuh/ } \\
\text { latihan }\end{array}$ & 1,000 & 1,133 & $028-4,58$ \\
\hline \multicolumn{1}{c}{ Dari tabel } & diatas & terlihat & bahwa adanya
\end{tabular}

interaksi antara status gizi dengan pola asuh/latihansetelah dimasukkan variabel pola asuh didapatkan nilai $\mathrm{p}=0,00$. Keadaan ini memberikan gambaran bahwa status gizi dengan perkembangan anak usia 1-2 tahun memberikan efek yang berbeda pada mereka yang pola asuh/latihannya kurang dan pola asuh/latihannya baik. 
Tabel 4.Uji Confounding variabel yang ikut dalam model Hubungan Status Gizi dengan Perkembangan anak usia 1-2 tahun di Puskesmas Warunggunung Tahun 2013

\begin{tabular}{cccc}
\hline $\begin{array}{c}\text { Variabel } \\
\text { yang } \\
\text { dimasukkan }\end{array}$ & $\begin{array}{c}\text { OR } \\
\text { Sebelum } \\
\text { dimasukkan }\end{array}$ & $\begin{array}{c}\text { OR Setelah } \\
\text { dimasukkan }\end{array}$ & $\begin{array}{c}\text { Selisih } \\
\text { OR }\end{array}$ \\
\hline $\begin{array}{c}\text { Pola } \\
\text { asuh/latihan }\end{array}$ & 37,315 & 31,825 & $14,7 \%$ \\
\hline
\end{tabular}

Dari seleksi Confounding terlihat bahwa variabel pola asuh bukan merupakan Confounding terhadap hubungan antara status gizi dengan perkembangan anak usia 1-2 tahun.

Tabel 5. Model Akhir Regresi Logistik Ganda

Hubungan Status Gizi dengan perkembangan anak usia 1-2 tahun di Puskesmas Warunggunung Tahun 2013

\begin{tabular}{cccccc}
\hline Variabel & $\mathrm{B}$ & $\mathrm{SE}$ & $\mathrm{Pv}$ & $\mathrm{OR}$ & $95 \%$ CI \\
\hline Status & 3,460 & 0,646 & 0,000 & 31,825 & $8,969-$ \\
Gizi & & & & & 112,928 \\
\hline Constant & 0,642 & 0,391 & 0,100 & 0,526 & \\
\hline
\end{tabular}

Dari keseluruhan proses analisis dapat disimpulkan bahwa dari enam variabel independen (Status Gizi, Jenis Kelamin, Pendidikan Ibu, Pekerjaan Ibu, Status sesial ekonomi, Pola asuh/latihan) yang diduga berhubungan dengan perkembangan anak usia 1-2 tahun, ternyata hanya variabel status gizi yang secara signifikan berhubungan dengan perkembangan anak usia 1-2 tahun di puskesmas Warungunung tahun 2013.

Anak yang memiliki status gizi kurang memiliki risiko untuk mengalami adanya penyimpangan perkembangan pada anak usia 1-2 tahun sebesar 31 kali dibandingkan dengan status gizi anak baik.

\section{Pembahasan}

Masa anak di bawah lima tahun merupakan periode penting dalam tumbuh kembang anak karena pertumbuhan dasar yang berlangsung pada masa balita akan mempengaruhi dan menentukan perkembangan anak selanjutnya. Seperti diketahui bahwa tiga tahun (baduta) pertama merupakan periode keemasan (golden period), yaitu terjadi optimalisasi proses tumbuh kembang. Dalam pertumbuhan dan perkembangan anak memerlukan zat gizi agar proses pertumbuhan dan perkembangan berjalan dengan baik. Zatzat gizi yang dikonsumi baduta akan berpengaruh pada status gizi baduta.

Perbedaan status gizi baduta memiliki pengaruh yang berbeda pada setia perkembangan anak, apabila gizi seimbang yang dikomsumsi tidak terpenuhi, pencapaian pertumbuhan dan perkembangan anak terutama perkembangan motorik yang baik akan terhambat. (Wiekke O, 2007).

Hasil penelitian kami menunjukan bahwa masih terdapat penyimpangan perkembangan pada anak usia 1-2 tahun $(23,0 \%)$ di wilayah kerja Puskesmas Warunggunung. Hal ini menunjukan masih rendahnya tingkat kesadaran dan pengetahuan yang dianut oleh masyarakat terutama orang tua anak usia 1-2 tahun, dan kurangnya sosialisasi dari tenaga 
kesehatan tentang pentingnya perkembangan anak usia 1-2 tahun.

Status gizi sangat berpengaruh pada pertumbuhan dan perkembangan balita. Status gizi balita merupakan hal penting yang harus diketahui oleh setiap orang tua. Status gizi juga berpengaruh pada kecerdasan balita, balita dengan gizi kurang atau buruk akan memiliki tingkat kecerdasan yang lebih rendah, nantinya mereka tidak mampu bersaing (Anonim, 2007)

Status gizi yang baik penting bagi kesehatan dan kesejahteraan setiap orang. Seseorang hanya akan cukup gizi jika makanan yang dimakan mampu menyediakan zat penting yang diperlukan tubuh. Proses pertumbuhan seorang anak terdiri atas dua proses yang tidak dapat dipisahkan karena saling mempengaruhi salah satunya yaitu proses pertumbuhan yang ditandai oleh semakin besarnya ukuran tubuh yaitu berat badan dan tinggi badan (Santoso dan Rianti, 2004).

Hal ini sesuai dengan tinjauan teori bahwa status gizi atau pemenuhan kebutuhan nutrisi merupakan salah satu faktor yang mempengaruhi perkembangan. Apabila kebutuhan nutrisi tidak atau kurang terpenuhi maka dapat menghambat pertumbuhan dan perkembangan (Hidayat, 2007). Hasil penelitian ini juga sesuai dengan teori yang menyebutkan bahwa seseorang yang memiliki status gizi baik atau normal maka refleksi yang diberikan adalah pertumbuhan normal, tingkat perkembangan sesuai dengan usianya, tubuh menjadi sehat, nafsu makan baik dan mudah menyesuaikan diri dengan lingkungan (Soekirman, 2002).

Pada tahun pertama tidak ada perbedaan vokalisasi antara wanita dan pria, tetapi pada usia dua tahun anak perempuan menunjukkan perkembangan yang lebih cepat dari anak lakilaki. Tidak dapat dipungkiri bahwa jenis kelamin akan mempengaruhi baik secara fisik maupun mentalnya. Secara fisik, anak laki-laki lebih kuat dan memiliki komposisi otot yang lebih banyak dari anak perempuan, selain itu secara mental biasanya laki-laki lebih mengutamakan ego daripada perasaan. Sedangkan perempuan lebih peka dan lebih sensitive terhadap keadaan di sekitarnya.

Sementara Menurut Sutjiningsih, (1995), anak laki-laki sering sakit dibandingkan anak perempuan, sehingga hal ini akan berpengaruh terhadap pertumbuhan dan perkembangan anak, tetapi belum diketahui secara pasti faktor penyebabnya.

Ibu yang bekerja dan tidak bekerja tidak mempengaruhi terhadap perkembangan anaknya, menurut pengamatan penulis bahwa pekerjaan ibu yang menjadi responden lebih banyak sebagai buruh, walaupun ibu bekerja tetapi anaknya masih dapat diasuh oleh anggota keluarga yang lainnya, sehingga kebutuhan bermain dan sosialisasi tidak menjadi kendala yang berati bagi perkembangan anak. 
Pendapatan keluarga yang memadai akan menunjang tumbuh kembang anak kareana orang tua dapat menyediakan semua kebutuhan anak, baik kebutuhan primer maupun kebutuhan skunder (Soetjianingsih, 1995).

Menurut Grantham dalam Surasmaji, (2008) Tingkat ekonomi yang rendah berhubungan dengan tingkat sanitasi dan kesehatan yang buruk dan kurangnya akses terhadap makanan bergizi yang meningkatkan risiko terjadinya infeksi dan gizi kurang. Tingkat sosial ekonomi juga berhubungan dengan rendahnya tingkat pendidikan ibu, meningkatnya stres dan depresi pada ibu, serta kurangnya stimulasi dirumah. Oleh karena itu sosial ekonomi yang rendah dapat menghalangi anak mencapai potensi pertumbuhan dan perkembangannya.

Perkembangan pada anak memerlukan rangsangan atau stimulasi khususnya dalam keluarga. Misalnya dalam penyediaan alat bermain, sosialisasi anak, keterlibatan ibu dan anggota keluarga lain dalam kegiatan anak. Kegiatan stimulasi, deteksi dan intervensi deteksi dini penyimpangan perkembangan anak yang menyeluruh dan terkoordinasi diselenggarakan dalam bentuk kemitraan antara keluarga (orang tua, pengasuh anak dan anggota keluarga lainnya), masyarakat (kader, tokoh masyarakat, organisasi profesi, LSM dan sebaginya) dan tenaga profesional (kesehatan, pendidikan dan sosial) akan meninkatkan kualitas tumbuh kembang anak usia dini dan kesiapan memasuki jenjang pendidikan formal. (Depkes, 2006)

Secara teori bahwa faktor kebutuhan stimulasi atau latihan terhadap anak untuk memperkenalkan suatu pengetahuan ataupun keterampilan baru ternyata sangat penting dalam peningkatan kecerdasan anak. Stimulasi pada anak dapat dimulai sejak calon bayi berwujud janin, sebab janin bukan merupakan makhluk yang pasif.

Berdasarkan dari bentuk kecerdasan yang perlu dikembangkan, mengharuskan stimulasi yang beragam pula. Salah satu yang utama stimulasi motorik, alasannya perkembangan motorik anak usia balita sangat pesat, terutama motorik kasar. Perkembangan motorik kasar diusia balita terkait erat dengan perkembangan fisik dan rasa percaya diri. Apabila pada usia tertentu anak belum bisa melakukan motorik kasar, maka anak telah mengalami keterlambatan (Tedjasaputra, 2003).

\section{Simpulan}

Masih terdapat penyimpangan perkembangan pada anak usia 1-2 tahun (23,0\%) di Puskesmas Warunggunung tahun 2013. Variabel status gizi mempunyai hubungan yang bermakna dengan perkembangan anak usia 1-2 tahun, sementara variabel jenis kelamin anak, pendidikan ibu, 
pekerjaan ibu, status sosial ekomoni dan pola asuh tidak berhubungan.

\section{Saran.}

Bagi Petugas kesehatan hendaknya melakukan pemantauan perkembangan anak sesuai dengan program Puskesmas secara rutin khususnya pada anak usia keemasan (golden age). Sekaligus memberikan penjelasan pada ibu yang memiliki anak usia keemasan tersebut tentang manfaat dan pentingnya gizi bagi pertumbuhan dan perkembangan anak, sehingga perkembangan anak usia keemasan sesuai dengan yang semestinya dan tidak ada lagi penyimpangan perkembangan.

\section{Daftar Pustaka}

Arikunto, 2010. Prosedur Penelitian : Suatu Pendekatan Praktek, Rineka Cipta. Jakarta

Arisman MB. 2007. Gizi Dalam Daur Kehidupan: Buku Ajar Ilmu Gizi. Penerbit. Buku Kedokteran EGC: Jakarta.

Departemen Kesehatan RI, 2006, Pedoman Pelaksanaan Stimulasi, Deteksi, dan Intervensi Dini Tumbuh Kembang Anak Di Tingkat Pelayanan Dasar,Jakarta.

Gladys Gunawan dkk, 2010, Hubungan status Gizi dengan Perkembangan Anak Usia 12 tahun, FK-Unpad Bandung.

Hosmer, D. W., \& Lemeshow, S. (1997). Applied Survival. Analysis Regression Modeling of Time to Event Data. New York:
Husein Umar, 2000, "Metode Penelitian Untuk Skripsi dan Tesis", Jakarta, Raja Grafindo Persada

Notoatmodjo, Soekijo. 2010. Metodologi Penelitian Kesehatan. Penerbit PT. Rineka Cipta. Jakarta

Puskesmas Warunggunung, 2013 Input data bulanan Kinerja Pembinaan Gizi Masyarakat,

RISKESDAS. Riset Kesehatan Dasar 2007. Jakarta: Badan Penelitian dan Pengembangan Kesehatan, Departemen Kesehatan, Republik Indonesia.

Soetjiningsih. 1995, Penilaian Pertumbuhan Fisik Anak. Dalam: IGN Gde Ranuh, penyunting.Tumbuh Kembang Anak.Jakarta: UKK Tumbuh Kembang IDAI;.h. 37-54.

Sunarti E. 2004. Mengasuh dengan Hati. Jakarta: PT Elex Media Komputindo.

Sutrisno Hadi, 1992, Statistik, Jilid 1, Yogyakarta, Yayasan Penerbit Fakultas Psikologi Universitas Gadjah Mada

Surasmanji, 2008 Pengaruh Status Gizi Dan Sosial Ekonomi Terhadap Onset Pubertas Laki-Laki Di Perkotaan Dan pedesaan, Tesis, Undip Semarang 